\title{
IDENTIFIKASI POTENSI DESA MOJO KECAMATAN KALITIDU KABUPATEN BOJONEGORO SEBAGAI DESA WISATA BERDASARKAN COMMUNITY BASED TOURISM (CBT)
}

\author{
Agus Sutedjo \\ Jurusan Pendidikan Geografi - Fakultas Ilmu Sosial dan Hukum - Unesa
}

\begin{abstract}
Abstrak : Desa Wisata Mojo terletak di Kecamatan Kalitidu Kabupaten Bojonegoro, dengan empat macam atraksi wisata didalamnya, ingin berusaha menarik wisatawan sebanyak-banyaknya. Sampai saat ini keinginan tersebut belum terwujud, jumlah wisatawan yang berkunjung di desa wisata Mojo sangat sedikit. Berkaitan dengan kondisi tersebut ingin diidentifikasi potensi wisata Desa Wisata Mojo untuk digunakan sebagai modal pengembangan kepariwisataan berbasis masyarakat, meliputi daya tarik atraksi, aksesibilitas, sarana dan prasarana, SDM, motivasi mayarakat, kondisi fisik geografis, dan interaksi dengan objek wisata lain. Untuk mencapai hal itu digunakan pengunjung sebanyak 100 responden sebagai sampel penelitian. Selanjunya dilakukan wawancara untuk mengeathui daya tarik atraksi wisata susur sungai, petik blimbing dan edukasi pengolahan blimbing, serta kondisi tempat perkemahan, data yang diperoleh dianalisis secara deskriptif.Wawancara terstruktur juga dilakukan untuk mengetahui motivasi dan SDM pengelola Desa Wisata Mojo. Untuk mengetahui kondisi fisik geografis dan interaksi antar objek wisata dilakukan observasi dan dokumenter, selanjutnya data yang dihasilkan dianalisis secara deskriptif. Hasil penelitian menunjukkan bahwa atraksi yang terdapat di Desa Wisata Mojo termasuk menarik,tingkat SDM pengelola termasuk sedang dan motivasi untuk mengembangkan desa wisata tergolong sedang. Sarana dan prasarana wisata yang ada secara kualitas maupun kuantitas termasuk belum memadai untuk pelayanan kepada wisatawan. Dengan lokasi wisata terdekat mempunyai interaksi yang tinggi sehingga berpotensi untuk menarik wisatawan dari wisata terdekat untuk berkunjung ke Desa Wisata Mojo. Beberapa kondisi fisik geografis menguntungkan untuk pengembangan kepariwisataan, namun juga terdapat faktor yang merugikan pengembangan yaitu banjir.
\end{abstract}

Kata kunci: atraksi, SDM, motivasi, sarana prasarana, interaksi, kondisi fisik

\section{A. PENDAHULUAN}

Sunaryo (2013) menyatakan bahwa masyarakat sebagai salah satu pemangku kepentingan memiliki kedudukan dan peran penting dalam mendukung keberhasilan pembangunan pariwisata, mulai dari kerangka perencanaan hingga pelaksanaan kegiatan pembangunan kepariwisataan. Untuk mendukung keberhasilan pembangunan kepariwisataan maka setiap upaya atau program pembangunan yang dilaksanakan harus memperhatikan posisi, potensi, dan peran masyarakat

Korespondensi:

e-mail: agussutedjo@unesa.ac.id 
sebagai pelaku pembangunan. Salah satu konsep yang menjelaskan peranan masyarakat tersebut dalam pembangunan pariwisata adalah Community Based Tourism (CBT).

CBT merupakan bentuk pariwisata yang memberikan kesempatan kepada masyarakat lokal untuk mengontrol dan terlibat dalam manajemen dan pembangunan pariwisata, masyarakat yang tidak terlibat langsung dalam usaha-usaha pariwisata juga mendapat keuntungan, menuntut pemberdayaan secara politis dan demokratisasi dan distribusi keuntungan kepada komunitas yang kurang beruntung di pedesaan (Hermantoro, 2011). CBT atau kepariwisataan berbasis masyarakat merupakan pendekatan pembangunan kepariwisataan yang menekankan pada masyarakat lokal baik yang terlibat langsung dalam industri pariwisata atau tidak.

Secara konseptual, prinsip dasar kepariwisataan berbasis masyarakat adalah menempatkan masyarakat sebagai pelaku utama melalui pemberdayaan masyarakat dalam berbagai kegiatan kepariwisataan, sehingga manfaat kepariwisataan sebesar-besarnya diprioritaskan keperuntukannya bagi masyarakat. Sasaran utama pengembangan kepariwisataan haruslah meningkatkan kesejahteraan masyarakat setempat di kawasan pembangunan pariwisata. Wujud dari konsep CBT adalah dikembangkannya desa-desa wisata, dimana dalam desa wisata, masyarakat desa yang berada di wilayah pariwisata mengembangkan potensinya baik potensi sumber daya alam, budaya, dan juga potensi sumber daya manusianya (masyarakat setempat).

Pada prinsipnya, mengembangkan Desa Wisata berarti memanfaatkaan sarana dan prasarana yang dimiliki masyarakat setempat serta pengembangan produk wisata pedesaan untuk melakukan kegiatan usahanya. Skala usaha yang dilakukan biasanya relatif kecil, namun harus tetap memberi keuntungan kepada masyarakat. Produkproduk wisata yang dikembangkan seperti atraksi, akomodasi, souvenir dan sebagainya merupakan produk khas masyarakat setempat dengan maksud untuk meningkatkan daya tarik terhadap wisatawan.

Pelibatan masyarakat secara langsung dan pemberdayaan masyarakat berperanan penting dalam tingkat keberhasilan pengembangan Desa Wisata (Purbasari dan Asnawi, 2014). Hal itu tidak jauh berbeda dengan hasil penelitan oleh Zakaria dan Supriharjo (2014). Pelibatan dalam berbagai 
kegiatan maupun pemberdayaan masyarakat dalam pengelolaan Desa Wisata akan menjadikan optimalnya pengelolaan segenap potensi yang dimiliki Desa Wisata sehingga meningkatkan dayatarik wisatanya. Dampaknya adalah meningkatnya jumlah wisatawan yang berkunjung.

Kualitas Sumber Daya Manusia (SDM) yang memadai sangat diperlukan dalam pengelolaan Desa Wisata, keberhasilan pengelolaan ditentukan oleh kualitas SDM yang tinggi, oleh karena itu mengetahui kualitas pendidikan masyarakat sangatlah penting (Syafi'i dan Suwandono, 2015). Peningkatan kualitas SDM masyarakat dapat dilakukan melalui berbagai program, seperti program : 1) pelayanan prima usaha pariwisata, 2) pelatihan dan peningkatan seni budaya lokal, 3) pelatihan pengembangan usaha Desa Wisata, 4) pengelolaan Desa Wisata, 5) pemeliharaan ketentraman, keamanan, ketertiban masyrakat dan bencana alam. Pendapat tersebut tidak jauh berbeda dengan Hadiwijoyo (2012) yang mengatakan bahwa pengeloaan Desa Wisata memerlukan Sumber Daya Manusia yang berkualitas.

Dalam kepariwisataan, daya tarik atraksi merupakan faktor yang sangat menentukan dalam menarik wisatawan untuk berkunjung ke objek wisata, makin menarik objek wisata yang ada di suatu tempat makin besar pula kemungkinan untuk dikunjungi wisatawan. Rizkianto dan Topowijono (2018) menjelaskan bahwa daya tarik Desa Wisata akan meningkat apabila terdapat sesuatu yang khas daerah setempat yang dapat dilihat, dirasakan, dilakukan, maupun dibawa pulang oleh wisatawan. Untuk mendapatkan hal itu dapat dilakukan penggalian secara mendalam tentang potensi alam, sosial budaya, maupun buatan masyarakat setempat untuk dijadikan atraksi wisata

Selain atraksi, aksesibilitas dan sarana prasarana pariwisata merupakan unsur penting dalam kepariwisataan. Aksesibilitas Desa Wisata yang tinggi berarti mudah dijangkau oleh wisatawan sehingga dimungkinkan untuk dikunjungi banyak wisatawan. Aksesisibilitas dipengaruhi oleh berbagai faktor seperti kondisi wisatawan, kondisi alam maupun teknologi, dan dapat diukur dengan jarak, waktu maupun biaya. Sedangkan sarana dan prasarana kepariwisataan merupakan unsur penunjang yang diperlukan oleh wisatawan dalam menikmati atraksi wisatanya. Sarana dan prasarana yang dapat memenuhi keinginan wisatawan akan membuat rasa senang, puas dan nyaman wisatawan 
yang berdampak pada jumlah wisatawan yang berkunjung.

Motivasi dari masyarakat tempat terdapatnya desa wisata sangat diperlukan dalam mendukung pengembangan dan menjaga keberlangsungan desa wisata. Motivasi berkaitan dengan dorongan seseorang dari dalam dirinya untuk menggapai keinginannya. Motivasi masyarakat yang tinggi dalam mengembangkan desa wisata akan berdampak pada tingkat keberhasilan yang ingin diraihnya.

Hal utama dalam bidang kepariwisataan adalah daya tarik objek wisata, tidak terkecuali di Desa Wisata. Berkaitan dengan pembangunan Desa wisata, untuk meningkatkan daya tarik wisatanya, secara umum dapat dibangun eco-loge, eco-recreation, eco-education, eco-research, eco-energy, ecodevelopment, eco-promotion (Kemenpar, 2016).

Berdasarkan ASEAN Community Based Tourism Standard (2016), potensi suatu desa untuk dijadikan sebagai Desa Wisata harus memenuhi persyaratanpersyaratan, antara lain sebagai berikut :

1. Aksesbilitasnya baik, sehingga mudah dikunjungi wisatawan dengan menggunakan berbagai jenis alat transportasi.

2. Memiliki obyek-obyek menarik berupa alam, seni budaya, legenda, makanan lokal, dan sebagainya untuk dikembangkan sebagai obyek wisata.

3. Masyarakat dan aparat desanya menerima dan memberikan dukungan yang tinggi terhadap desa wisata serta para wisatawan yang datang ke desanya.

4. Keamanan di desa tersebut terjamin.

5. Tersedia akomodasi, telekomunikasi, dan tenaga kerja yang memadai.

6. Beriklim sejuk atau dingin.

7. Berhubungan dengan obyek wisata lain yang sudah dikenal oleh masyarakat luas.

Desa Mojo Kecamatan Kalitidu Kabupaten Bojonegoro telah berdiri Desa Wisata yang dikelola oleh Kelompok Sadar Wisata Desa Mojo. Semenjak berdiri pada tahun 2015 sampai dengan tahun 2018, berbagai upaya telah dilakukan untuk mengembangkan Desa Wisata agar supaya dapat menarik wisatawan untuk berkunjung. Terdapat kegiatan petik buah blimbing pada Kebun Blimbing yang cukup luas (6 ha), wisata edukasi, areal untuk berkemah, dan susur sungai sebagai atraksi wisatanya, yang semua kegiatannya berdekatan dengan alam. Hal tersebut sebenarnya telah sesuai dengan aktivitas yang seharusnya dalam Desa Wisata. Namun demikian, dalam usahanya untuk mendatangkan wisatawan sebanyak-banyaknya belum 
seperti diharapkan. Jumlah wisatawan yang berkunjung ke Desa Wisata Mojo relatif kecil, rata-rata 14.403 wisatawan setiap tahun. Padahal di lokasi tersebut terdapat 4 macam kegiatan yang dapat dilakukan oleh wisatawan, artinya ratarata kurang dari 15 orang setiap minggu yang berkunjung di setiap lokasi. Terlebih lagi pada kegiatan petik buah blimbing, yang semestinya buah blimbing diperuntukkan untuk dipetik oleh wisatawan dan harapannya dihabiskan oleh pengunjung ternyata hanya sebagian kecil buah blimbing yang terbeli oleh wisatawan, sebagian besar buah blimbing dijual ke pedagang. Dari aspek ekonomi, kemungkinan pemilik kebun blimbing tidak mengalami kerugian, namun dari aspek kepariwisataan menunjukkan ketidak berhasilan dalam memajukan kepariwisataan Desa Wisata Mojo. Ratarata roduksi blimbing setiap tahun 1040 ton namun jumlah yang terjual di kebun blimbing hanya 64 ton (Kelompok Sadar Wisata Mojo 2019).

Berdasarkan latar belakang permasalahan yang diuraikan seperti di atas, maka tujuan penelitian adalah mengidentifikasi potensi wisata Desa Wisata Mojo untuk digunakan sebagai modal pengembangan kepariwisataan berbasis masyarakat, meliputi daya tarik atraksi, aksesibilitas, sarana dan prasarana, SDM, motivasi mayarakat, keamanan, kondisi fisik geografis, dan interaksi dengan objek wisata lain.

\section{B. METODE}

\section{Lokasi Penelitian.}

Penelitian ini merupakan penilitian survey yang dilakukan di Desa Mojo Kecamatan Kalitidu Kabupaten Bojonegoro. Desa tersebut telah mengembangkan beberapa atraksi untuk kegiatan wisata desa, yakni petik buah belimbing, wisata edukasi tanaman blimbing, susur sungai, dan kemah. Survey dilakukan ditempat atraksi berada, meliputi aspek fisik maupun sosial dan dimungkinkan di tempat lain yang berkaitan dengan atraksi tersebut.

\section{Populasi dan Sampel Penelitian.}

Populasi dalam peneltian ini adalah wisatawan yang berkunjung di masing-masing objek wisata yaitu Kebun Blimbing, Wisata Edukasi, Susur Sungai dan Berkemah. Selanjutnya diambil secara insidental sejumlah 100 wisatawan sebagai sampel penelitian yang tersebar di ke empat lokasi objek wisata. Masyarakat Desa Mojo juga merupakan populasi penelitian yang akan diwakili pengurus Kelompok Sadar wisata (pengelola).

\section{Teknik Pengambilan Data.}

Data yang diambil dalam penelitian ini meliputi data primer 
maupun data sekunder melalui observasi, wawancara, dan pengukuran. Teknik pengambilan data yang digunakan dalam penelitian adalah melalui observasi, wawancara, pengukuran, dan dokumentasi.

\section{Analisis Data}

Untuk mengidentifikasi potensi wisata Desa Mojo menggunakan variabel-variabel seperti di bawah ini, selanjutnya masing-masing variabel diananilis.

Daya Tarik Atraksi. Pengukuran
daya tarik dilakukan dengan
menggunakan Skala Likert berdasarkan
skor jawaban responden terhadap
masing-masing objek wisata atas
beberapa pertanyaan yang diajukan.

Aksesibilitas. Pengukuran aksesibilitas berdasarkan jarak menggunakan satuan km, waktu dengan satuan menit dan kondisi sarana dan prasarana transportasi umum, diukur dari ibukota kecamatan dan ibukota kabupaten.

Sarana dan Prasarana. Pengukuran dilakukan menggunakan sejumlah kriteria kuntitas maupun kualitas sehingga dapat diketahui kondisi sarana dan prasarana yang ada.

- $\quad$ Sumber Daya Manusia. Dalam peneitian ini diukur tentang tingkat pendidikan formal maupun non formal yang pernah ditempuh dan pengalaman kerja dalam bidang kepariwisataan oleh pengelola Desa Wisata Mojo. Selanjutnya dilakukan penskoran sehingga tingkat Sumber Daya Manusia pengelola Desa Wisata Mojo dapat diketahui.

Motivasi masyarakat. Pengukuran motivasi dilakukan dengan menggunakan Skala Likert berdasarkan skor jawaban responden (pengelola desa wisata) dari beberapa pertanyaan yang diajukan untuk tingkat motivasinya.

- Interaksi dengan objek wisata lain. Secara potensial pengukuran interksi dapat menggunakan rumus seperti berikut.

$$
I_{A-B}=\frac{P_{A} \times P_{B}}{J_{A-B}{ }^{2}}
$$

Dalam hal ini,

$\mathrm{I}_{\mathrm{A}-\mathrm{B}} \quad$ : interaksi antara objek wisata $\mathrm{A}$ dan B

$\mathrm{J}_{\mathrm{A}-\mathrm{B}}{ }^{2} \quad$ : kuadrat jarak antara objek wisata A dan B

$\mathrm{P}_{\mathrm{A}} \quad$ : jumlah wisatawan di objek wisata A

$\mathrm{P}_{\mathrm{B}} \quad$ : jumlah wisatawan di objek wisata B

- Kondisi Fisik Geografis.

Merupakan karakter fisik yang melekat pada Desa Mojo, terdiri dari karakter hujan, penggunaan lahan, topografi, airtanah, air permukaan, iklim, geologi dan geomorfologi. Analisis dilakukan secara deskriptif 
pada masing-masing aspek berdasarkan kondisi di lapangan saat ini.

C. HASIL DAN PEMBAHASAN

\section{Gambaran Umum Daerah Penelitian}

\section{a. Lokasi}

Daerah penelitian yaitu Desa Mojo terletak di bagian utara Kabupaten Bojonegoro, dan sebelah barat Kota Bojonegoro. Desa Mojo berbatasan dengan Desa Pagerwesi, Kecamatan Trucuk di sebelah utara, berbatasan dengan Desa Padang, Kecamatan Trucuk di sebelah timur, berbatasan dengan Desa Ngringinrejo Kecamatan Kalitidu di sebelah selatan, dan di sebelah barat berbatasan dengan Desa Kandangan Kecamatan Trucuk.

Desa Mojo juga terletak 1,5 km dari jalur lalu lintas yang cukup ramai, yaitu Jalan Raya Cepu atau jalan raya Bojonegoro-Ngawi, dan merupakan jalur tengah antara Kota Bojonegoro ke Kota Rembang. Dari pusat Kecamatan Kalitidu berjarak $7 \mathrm{Km}$ ka arah timur sementara dari Bojonegoro berjarak 15 Km ke arah barat. Namun juga terletak sangat dekat, bahkan berbatasan langsung dengan Bengawan Solo, yakni sebagian besar panjang perbatasan Desa Mojo sekaligus badan Bengawan Solo.

\section{b. Iklim.}

Berdasarkan data suhu udara dan curah hujan bulanan di Kabupaten Bojonegoro, suhu rata-rata harian di Desa Mojo $31{ }^{\circ} \mathrm{C}$, suhu rata-rata terendah adalah $27^{\circ} \mathrm{C}$ sedangkan suhu rata-rata tertinggi sebesar $35^{\circ} \mathrm{C}$. Untuk menentukan iklim di Desa Mojo digunakan metode Schmith-Ferguson dengan menggunakan data hujan bulanan, dari hasil perbandingan antara bulan bulan kering dan bulan basah diperoleh iklim di daerah Desa Mojo adalah Iklm E atau Agak Kering

Iklim agak kering tersebut mempunyai arti bahwa selama satu tahun, hujan yang jatuh relatif pendek atau udara cerah berlangsung lebih lama. Sementara itu atraksi wisata di Desa Wisata Mojo berada di areal terbuka, sehingga akan terganggu kegiatannya apabila terjadi hujan. Kondisi ini sangat menguntungkan untuk pengembangan kepariwisaataan, karena wisatawan akan menghindari hujan dalam menjalankan kegiatan wisatanya.

\section{c. Topografi}

Topografi daerah penelitian termasuk datar dengan ketinggian ratarata $25 \mathrm{~m}$ di atas permukaan laut. Antara satu tempat dengan tempat yang lain mempunyai perbedaan ketinggian yang sangat tipis sehingga tidak dijumpai adanya cekungan-cekungan permukaan 
bumi yang jelas. Perbedaan ketinggian antara permukaan air Bengawan Solo dengan permukaan tanah relatif kecil sehingga jika terjadi kenaikan permukaan air sungai mudah sekali terjadi genangan di daratan.

\section{d. Geologi /geomorfologi}

Secara geomorfologis, lokasi peneltian merupakan dataran banjir, luapan Bengawan Solo yang hampir setiap tahun banjir membawa material endapan sehingga membentuk endapan yang datar pada waktu kering. Sebagian besar endapan material berupa debu dan pasir halus yang membentuk alluvium sebagai batuan induk tanah. Batuan alluvium yang ada bekali-kali mengalami pembaharuan karena sering terjadi pengendapan baru akibat banjir. Lapisan-lapisan tanah yang nampak merupakan hasil pengendapan yang berulang-ulang.

Jenis batuan yang terbentuk mempunyai permebilitas dan porositas yang baik sehingga mampu meloloskan dan menyimpan air dengan baik. Secara geologis, di daerah penelitian lebih dominan gaya geologi berupa pengendapan sementara gaya-gaya yang lain seperti pelapukan, pengikisan, gempa bumi, dan letusan gunungapi tidak berpengaruh secara berarti terhadap perubahan muka bumi. Dengan demikian, bencana geologi yang dapat muncul terjadi tidak ada namun dapat terjadi bencana meteorologi yaitu banjir. Dari aspek geologi / geomorfologi, banjir yang sering terjadi di Desa Mojo akan mengendapkan material secara terus menerus. Endapan subur yang dibawa aliran Bengawan Solo akan menyuburkan tanah di Desa Mojo sehingga kesuburan tanahnya tetap terjaga. Kesuburan yang tetap terjaga ini akan menjaga tanaman blimbing tetap hidup dengan baik tanpa penambahan pupuk yang berarti. Hal ini sangat menguntungkan bagi para petani blimbing karena dapat mengurangi biaya produksi yang harus dikeluarkan.

\section{e. Keairan}

Ketersediaan air yang terdapat di daerah penelitian adalah airtanah, air sungai dan air hujan. Airtanah merupakan potensi air bersih yang paling baik di Desa Mojo sehubungan dengan karakter batuannya, ketersediannya cukup melimpah untuk keperluan penduduk sepanjang tahun. Airtanah dapat diambil dari sumursumur dengan kedalaman permukaan air sumur kurang dari 3 meter.

Untuk keperluan yang lain dalam jumlah besar, misalnya pertanian, dapat menggunakan air dari Bengawan Solo. Sungai tersebut cukup besar alirannya sehingga dapat dimanfaatkan untuk keperluan yang lain, misalnya industri, 
pariwisata, dan sebagainya. Namun perlu adanya perhatian karena pada waktu musim hujan sering terjadi banjir yang dapat mengganggu kegiatan seharihari masyarakat. Air hujan praktis tidak dimanfaatkan karena semua keperluan penduduk dapat dipenuhi dari airtanah dan air sungai.

Dari aspek keairan, disamping faktor yang merugikan karena adanya bencana banjir, Bengawan Solo dapat memasok air untuk kebutuhan wisatawan, baik melalui air tanah maupun air permukaan. Bengawan Solo akan menyediakan air secara berlimpah sehingga pengelola tidak akan kesulitan dalam penyediaan air, tinggal pengelolaan yang tepat yang harus dilakukan. Berkaitan dengan aspek geologi, sifat batuan di Desa Wisata Mojo dapat melalukan dan menyimpan air dengan baik menjadi airtanah, sehingga secara potensi airtanahnya bagus. Airtanah dapat digunakan secara langsung untuk keperluan wisatawan, karena kualitas airtanah cukup bagus, kecuali untuk air minum perlu dimasak terlebih dahulu.

Beberapa aspek kondisi fisik di Wisata Desa Mojo menguntungkan untuk pengembangan kepariwisataan selanjutnya namun juga terdapat hal-hal yang merugikan. Dari aspek lokasi, Desa Wisata Mojo yang terletak dipinggir
Bengawan Solo yang cukup besar dapat mengembangkan atraksi wisata air yang lain, tidak hanya susur sungai, agar supaya terdapat atraksi yang bervariasi. Kondisi yang sangat menguntungkan ini dapat digunakan sebagai modal oleh pengelola untuk pengembangan selanjutnya, namun dibalik sesuatu yang menguntungkan ini terdapat resiko yang cukup besar yakni banjir Bengawan Solo yang sering terjadi pada musim penghujan sebagai akibat hujan kiriman di daerah hulu. Bencana banjir merupakan salah satu faktor penghambat pengembangan kepariwisataan, karena wisatawan yang datang harus terlindungi dari bencana apapun termasuk banjir.

Penyebab banjir, disamping karena jumlah aliran sungai yang cukup besar, karena dipengaruhi juga oleh faktor topografi yang kurang menguntungkan. Bentuk daratan sangat datar, dan perbedaan ketinggian antara permukaan tanah dengan permukaan air sungai terlalu sedikit sehingga jika terjadi penambahan volume aliran sungai akan terjadi luapan atau banjir yang dapat menggenangi seluruh daratan Desa Mojo. Banjir ini sulit dihindari sehingga diperlukan langkah tertentu untuk mengurangi aliran yang menggenangi desa, misalnya dibuat tanggul di sepanjang tepi sungai meskipun biayanya sangat mahal. 
Dampak negatip banjir sangat besar, baik bagi masyarakat setempat maupun wisatawan yang berkunjung.

\section{Atraksi}

Atraksi yang dapat dinikmati wisatawan di Desa Wisata Mojo adalah susur perahu, kebun blimbing, wisata edukasi pengolahan blimbing, dan tempat perkemahan. Keempat lokasi atraksi tersebut letaknya relatif berdekatan. Adapun kondisi masingmasing atraksi adalah seperti berikut ini.

- Susur Perahu merupakan atraksi wisata mengendarai perahu menyusuri Bengawan Solo sepanjang kurang lebih $1 \mathrm{~km}$. Sepanjang perjalanan wisatawan dapat menikmati pemandangan perdesaan dan kebun blimbing yang dilewati. Berdasarkan pendapat wisatawan sebanyak 50 orang tentang susur perahu, daya tarik susur sungai adalah Sangat Menarik.

- Atraksi di tempat ini wisatawan dapat memetik blimbing yang sudah masak, kemudian dapat dimakan di tempat atau dibawa pulang setelah membayar terlebih dulu. Untuk mengetahui tingkat daya tarik Kebun Blimbing di desa Wisata Mojo digunakan sebanyak 100 pengunjung sebagai responden. Pendapat 100 pengunjung tentang kebun blimbing dan pelayanan pengelola kebun blimbing, daya tariknya termasuk Menarik.

- Wisata edukasi khusus diperuntukkan bagi siapapun yang menginnginkan untuk belajar budidaya pohon blimbing dan mengolah buah blimbing, dua kegiatan tersebut merupakan satu paket. Hasil pengisian angket dengan 15 peserta wisata edukasi tentang pelaksanaan kegitan wisata edukasi di Desa Wisata Mojo adalah Menarik.

- Tempat berkemah, tempat ini merupakan areal terbuka yang dapat digunakan untuk perkemahan terutama anak-anak sekolah atau remaja. Ukuran tempat berkemah tidak terlalu luas ( $75 \mathrm{~m}$ x 100m ) dan tidak jauh dari permukiman penduduk Hasil wawancara dengan 20 responden tentang kondisi tempat perkemahan di Desa Wisata Mojo termasuk Agak Baik.

Atraksi yang terdapat di Desa Wisata Mojo termasuk menarik, kecuali tempat perkemahan yang kondisinya agak baik untuk tempat perkemahan. Atraksi yang menarik biasanya akan didatangi oleh banyak wisatawan, hal ini sesuai pendapat Hall dan Page (2007) dan Rimsky (2017) bahwa atraksi yang menarik akan didatangi oleh banyak orang. Oleh karena untuk pengembangan Desa Wisata Mojo sudah 
mempunyai modal yang kuat untuk pengembangan di masa mendatang. Kondisi tersebut harus dimanfaatkan semaksimal mungkin karena tidak semua desa wisata mempunyai atraksi menarik lebih dari satu. Pengembangan lebih diarahkan kepada kualitas yang sudah ada, namun dapat juga secara kuantitas.

\section{Sumberdaya Manusia}

\begin{tabular}{lcr}
\multicolumn{2}{c}{ Kualitas } & maupun kuantitas \\
pengelola akan & menentukan tingkat \\
keberhasilan & pengelolaannya. \\
Berdasarkan tingkat pendidikan, \\
pengalaman mengelola, pelatihan
\end{tabular}
kepariwisataan yang pernah diikuti, dan umur; kualitas pengelola secara umum termasuk sedang. Motivasi pengelola secara internal maupun eksternal juga termasuk tingkat sedang. Kedua hal tersebut berakibat pada kurang maksimalnya dari pengelola dalam melaksanakan tugas yang diemban dalam mengelola Desa Wisata Mojo, sebagai contoh adalah kurang terawatnya beberapa sarana dan prasarana. Kesadaran yang tinggi dari pengelola untuk melaksanakan tanggungjawab yang diemban dalam mengembangkan kepariwisataan akan terbentuk apabila disertai dengan motivasi yang luar biasa.

Prabawati (2013) menjelaskan bahwa manajemen pariwisata yang baik akan menghasilkan pengembangan kepariwisataan berbasis masyarakat (CBT) yang berhasil pula. Dengan memperhatikan tingkat sumberdaya manusia di Desa Wisata Mojo merupakan hal wajar apabila pengembangan belum seperti apa yang diharapkan. Oleh karena itu diperlukan langkah tertentu untuk meningkatkan motivasi pengelola, mislnya melalui pembelajaran CBT di tempat lain yang sudah berhasil. Pada intinya meningkatkan pengetahuan dan ketrampilan pengelolaan dengan melihat secara langsung pengembangan CBT di tempat lain perlu dilakukan

\section{Interaksi}

Hasil interaksi paling kecil adalah antara desa Wisata Mojo dengan Kebun Jambu Kristal, hal ini menunjukkan bahwa potensi gerakan wisatawan dari desa Wisata Mojo ke Kebun Jambu Kristal atau sebaliknya paling sedikit. Sedangkan potensi gerakan wisatawan paling banyak dari Bendung Gerak ke Agowisata Kebun Blimbing Ngringinrejo. Dari hasil penelitian di lapangan ternyata tidak semua sesuai dengan potensinya. Jumlah wisatawan yang berkunjung dari Bendung Gerak ke Agowisata Kebun Blimbing dan sebaliknya sesuai dengan potensinya yakni paling besar diantara gerakan wisatawan antar objek wisata yang lain. 
Sementara gerakan wisatawan dari Agrowisata Kebun Blimbing ke Desa Wisata Mojo dan sebaliknya meskipun jaraknya dekat ternyata jumlah perpindahan wisatawan paling sedikit, meskipun besaran interaksinya cukup besar. Hal ini dimungkinkan Desa Wisata Mojo kalah menarik dibandingkan Agowisata Kebun Blimbing.

\section{Sarana dan Prasarana}

Untuk memenuhi kebutuhan selama perjalanannya atau di lokasi objek wisata, wisatawan memerlukan sarana dan prasarana kepariwisataan yang memadai. Kualitas dan kuantitas fasilitas kepariwisataan yang berada lokasi objek wisata akan dirasakan oleh pengunjung dan akan berpengaruh terhadap jumlah wisatawan yang akan berkunjung. Fasilitas kepariwisataan yang baik akan ditanggapi dengan baik oleh pengunjung, dan oleh pengunjung akan diinformasikan kepada pengunjung yang lain yang berdampak pada jumlah kunjungan wisatawan yang meningkat (Mill, 2010; Hadiwijoyo, 2012).

Kondisi sarana dan prasarana yang berada di Desa Wisata Mojo, baik secara kualitas maupun secara kuantitas masih belum memenuhi kelayakan. Fasilitas kepariwisataan yang ada banyak yang rusak, dan hanya kebaradaan air yang termasuk baik sehingga berpengaruh terhadap jumlah kunjungan wisatawan. Kondisi inilah yang diperkirakan berpengaruh terhadap sedikitnya jumlah wisatawa yang berkunjung. Untuk pengembangan selanjutnya, pengelola harus memperhatikan kondisi yang tidak mendukung ini.

\section{Aksesibilitas}

Kemudahan objek wisata untuk dijangkau oleh wisatawan merupakan salah satu syarat untuk pengembangan destinasi objek wisata agar cepat berhasil (Gunn, 2002; Hadiwijoyo, 2012). Keterjangkauan atau aksesibilitas tidak hanya tergantung pada jarak, namun juga ditentukan oleh faktor biaya dan waktu yang sangat berkaitan dengan kondisi wisatawan (Mill, 2010). Kondisi alam akan berpengaruh terhadap aksesibilitas namun pada jaman sekarang ini, hambatan aksesibilitas dapat diatasi dengan kemajuan teknologi sehingga faktor biaya akan menentukan.

Lokasi Desa Wisata Mojo termasuk mudah dijangkau oleh wisatawan, atau mempunyai aksesibilitas tinggi, yakni kondisi jalan bagus, jarak dari ibukota kecamatan atau ibukota kabupaten relatif dekat, tiket masuk juga relatif murah. Kondisi ini dapat mendorong Desa Wisata Mojo untuk lebih cepat berkembang dengan 
lebih banyak menarik wisatawan untuk berkunjung

Seperti yang dimaknai oleh Soemarno (2010), Desa Wisata Mojo belum berkembang menjadi desa wisata yang sebenarnya, belum terlihat adanya integrasi antara atraksi, akomodasi, dan fasilitas pendukung yang tersaji dalam struktur masyarakat yang menyatu dengan tatacara dan tradisi tertentu. Akomodasi belum dijumpai, sementara atraksi petik blimbing dan edukasi pengolahan blimbing belum sepenuhnya berjalan seperti yang diharapkan, sementara pada susur sungai tidak ada antara masyarakat dengan wisatawan. .

\section{KESIMPULAN DAN SARAN}

\section{Kesimpulan}

Berdasarkan hasil penelitian dan pembahasan seperti diuraikan di atas maka dapat ditarik kesimpulan seperti berikut.

a. Kondisi Fisik di Desa Wisata Mojo ada yang bersifat menguntungkan maupun merugikan pengembangan kepariwisataan. Kondisi iklim, air tanah, kesuburan tanah yang tetap terjaga, dan lokasi di pinggir sungai besar merupakan faktor yang menguntungkan, sedangkan banjir yang masih sering terjadi merupakan faktor yang dapat menghambat atau merugikan pengembangan kepariwisataan.

b. Sarana dan prasarana kepariwisataan yang terdapat di desa Wisata Mojo dalam kondisi yang kurang baik untuk pelayanan terhadap wisatawan, disamping itu jenisnya masih kurang seperti sarana dan prasarana kesehatan dan keamanan yang sangat diperlukan oleh wisatawan.

c. Atraksi wisata berupa susur sungai, petik buah blimbing dan wisata edukasi pengolahan blimbing merupakan atraksi yang menarik bagi wisatawan.

d. Tempat perkemahan belum didukung oleh ketersediaan sarana sebagai tempat perkemahan yang memadai.

e. Motivasi pengelola dalam mengembangkan Desa Wisata Mojo masih perlu ditingkatkan dan lebih banyak lagi melibatkan masyarakat.

\section{Saran}

Agar pengembangan Desa Wisata Mojo sesuai dengan harapan selanjutnya diperlukan berbagai upaya.

a. Penambahan sarana dan prasarana kepariwisataan pada bidang kesehatan, keamanan, akomodasi, pusat informasi dan perparkiran serta perbaikan sarana dan prasarana dalam bidang akomodasi, loket, 
toilet, tempat istirahat, tempat sampah dan tempat ibadah.

b. Peningkatan kualitas pengelola desa wisata dengan menambah frekuensi pelatihan dan jenis pelatihan.

c. Penambahan atraksi secara insidentil atau permanen dengan memanfaatkan aliran Bengawan Solo atau adat istiadat setempat.

d. Melakukan promosi melalui berbagai media.

\section{E. DAFTAR PUSTAKA.}

Association of Southeast Asian Nation. 2016. ASEAN Commmunity Based Toursm Standard. Jakarta, ASEAN Secretariat.

Zakaria, F. dan Supriharjo, R. D., 2014. Konsep Pengembangan Kawasan Wisata Desa Wisata Di Desa Bandungan Kecamatan Pakong Kabupaten Pamekasan. Jurnal teknik POMITS. Vol. 2, No. 2, 2.

Kementrian Pariwisata, 2016. Panduan Pembentukan Desa Wisata. Jakarta, Kemenpar

Gunn, C. A., 2002. Tourism Planning. Basic, Concept, Cases. Forth Edition. New York and London, Routledge.

Hall, L.M., Page, S.J., 2009. The Geography of Tourism and Recreation, Environtmen, Place and Space. London, Rotledge.

Hadiwijoyo, S. S., 2012. Perencanaan Pariwisata Pedesaan Berbasis Masyarakat (Sebuah Pendekatan Konsep). Yogyakarta, Graha Ilmu.
Hermantoro, H. 2011. Community Based Tourism. Dari Wisata Rekreatif Menuju Wisata Kreatif. Yogyakarta, Galang Press.

Mill, C.R.,. 2010. Toursm. The international Business. Edisi Bahasa Indonesia. Jakarta, PT Raja Grafindo Persada.

Syafi'I, M. dan Suwandono, D., 2015. Perencanaan Desa Wisata Dengan pendekatan Konsep community Based Tourism (CBT) Di Desa Bedono Kecamatan Sayung Kabupaten Demak. RUANG Vol.1, No.2, Hal 51-60, 2015.

Rizkianto, N. dan Topowijono. Penerapan Konsep Community Based tourism Dalam pengelolaan Daya Tarik Wisata Berkelanjutan - Syudi Pada Desa Wisata Kecamatan Munjungan kabupaten Trenggalek Jurnal Administrasi Bisnis. Vol. 58, no. 2, 2018.

\begin{tabular}{crr} 
Sunaryo, B., & 2013. & Kebijakan \\
Pemangunan & \multicolumn{2}{c}{ Destinasi } \\
Pariwisata & Konsep dan \\
Aplikasinya & di Indonesia. \\
Yogyakarta, Grava Media.
\end{tabular}

Purbasari, N. dan Asnawi, 2014. Keberhasilan Community Based Tourism Di Desa Kembagarum, Pentingsari, dan Nglanggeran. Jurnal Teknik PWK. Vol. 2, No.3, 2014

Rimsky, K.J., 2017. Aktivitas dan Kopleksitas Kepariwisataan. Jakarta, Gramedia Pustaka Utama.

Thomas Lopez Guzman, Victor Pavon, Sandra Sanches. Community Based Tourism in Developing Counties. A Case Study. Tourismos: An International Multidisciplinary Journal of Tourism. Vol. 6, No. 1, 69-84, 2011 